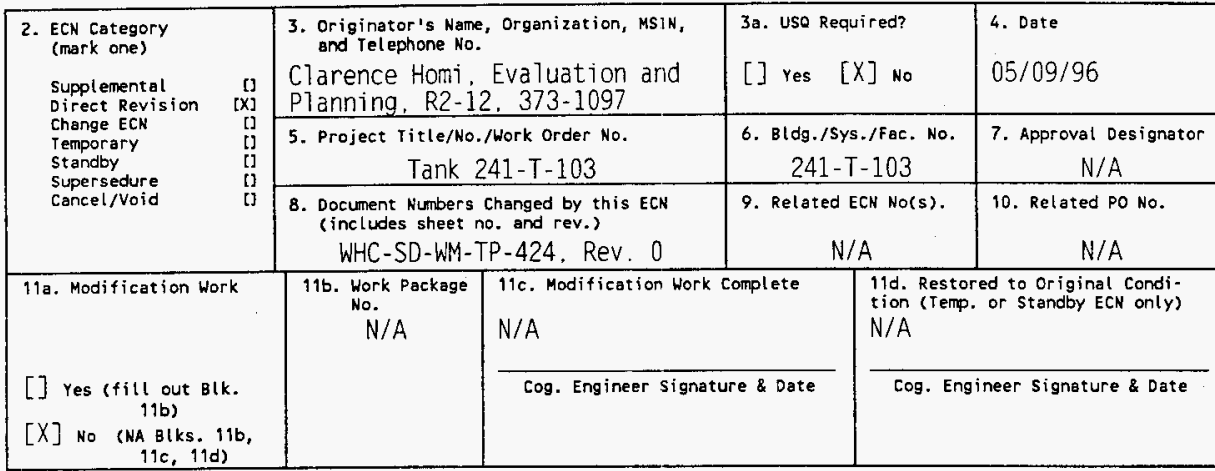

12. Description of Change

Complete revision.

13a. Justification (mark one)

$\begin{array}{llllllll}\text { Criteria Change } & {[X]} & \text { Design Improvement } & {[]} & \text { Environmental } & \text { [] } & \text { Facility Deactivation [] } \\ \text { As-Found } & {[]} & \text { Facilitate Const } & {[]} & \text { Const, Error/Omission } & \text { [] } & \text { Design Error/Onission }\end{array}$

13b. Just ification Details

Changed to comply with new template and DOE-RL recommended modifications.

14. Distribution (include name, MSIN, and no. of copies)

See attached distribution.

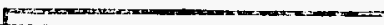

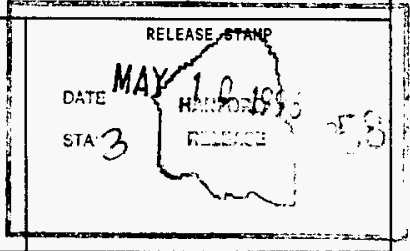

A-7900-013-2 (11/94) GEFO95 


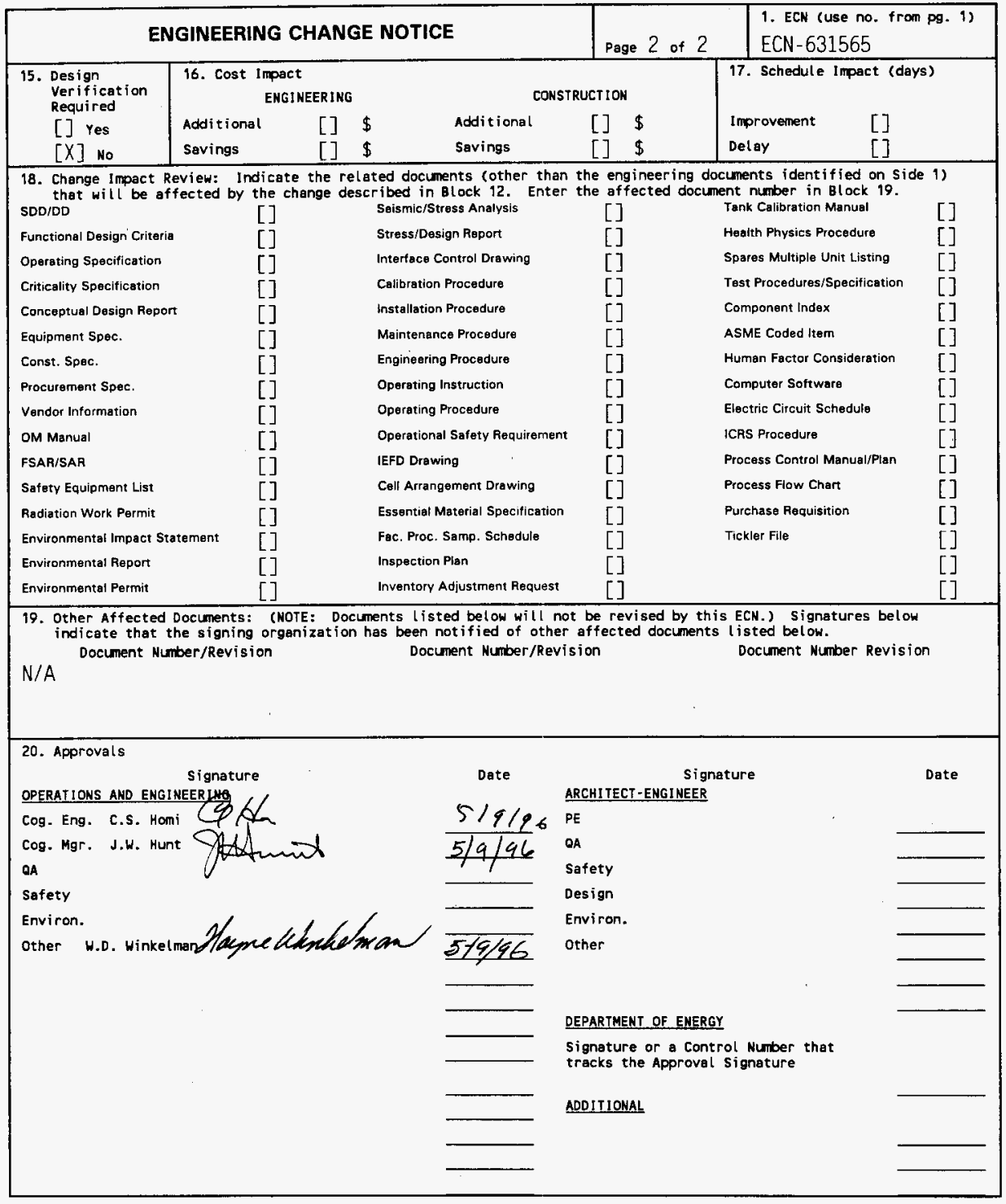




\section{Tank 241-T-103 Tank Characterization Plan}

C. S. Homi

Westinghouse Hanford Company, Richland. WA 99352

U.S. Department of Energy Contract DE-AC06-87RL10930

EDT/ECN: $E C N-631565$ UC: 2070

Org Code: 79200 Charge Code: N4G6A

B\&R Code: EW 3120074 Total Pages: 10

Key Words: Characterization. General Safety Issues. Specific Safety Issues, Information Requirements, Schedule

Abstract: This document is a plan that identifies the information needed to address relevant issues concerning short-term and long-term storage and long-term management of Single-Shell Tank (SST) 241-T-103.

TRADEMARK DISCLAIMER. Reference herein to any specific comercial product, process, or service by trade name, trademark, manufacturer, or otherwise, does not necessarily constitute or imply its endorsement, recommendation, or favoring by the United States Govermment or any agency thereof or its contractors or subcontractors.

Printed in the United States of America. To obtain copies of this document, contact: WHC/BCS Document Control Services, P.D. Box 1970, Mailstop H6-08, Richland WA 99352, Phone (509) 372-2420; Fax (509) 376-4989.
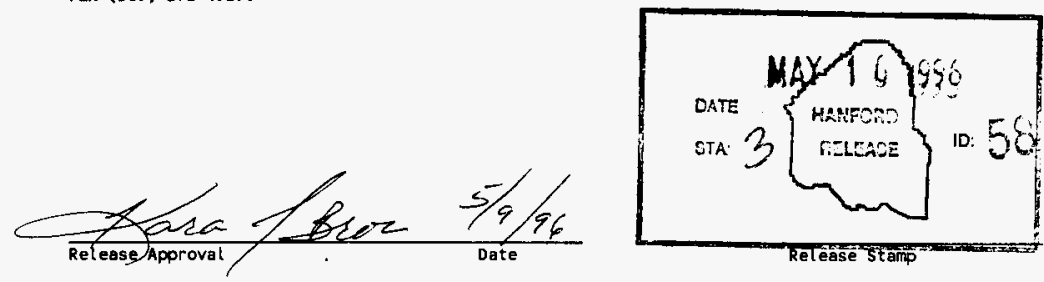

\section{Approved for Public Release}


RECORD OF REVISION

(2) Title

Tank 241-T-103 Tank Characterization Plan

CHANGE COHTROL RECORD

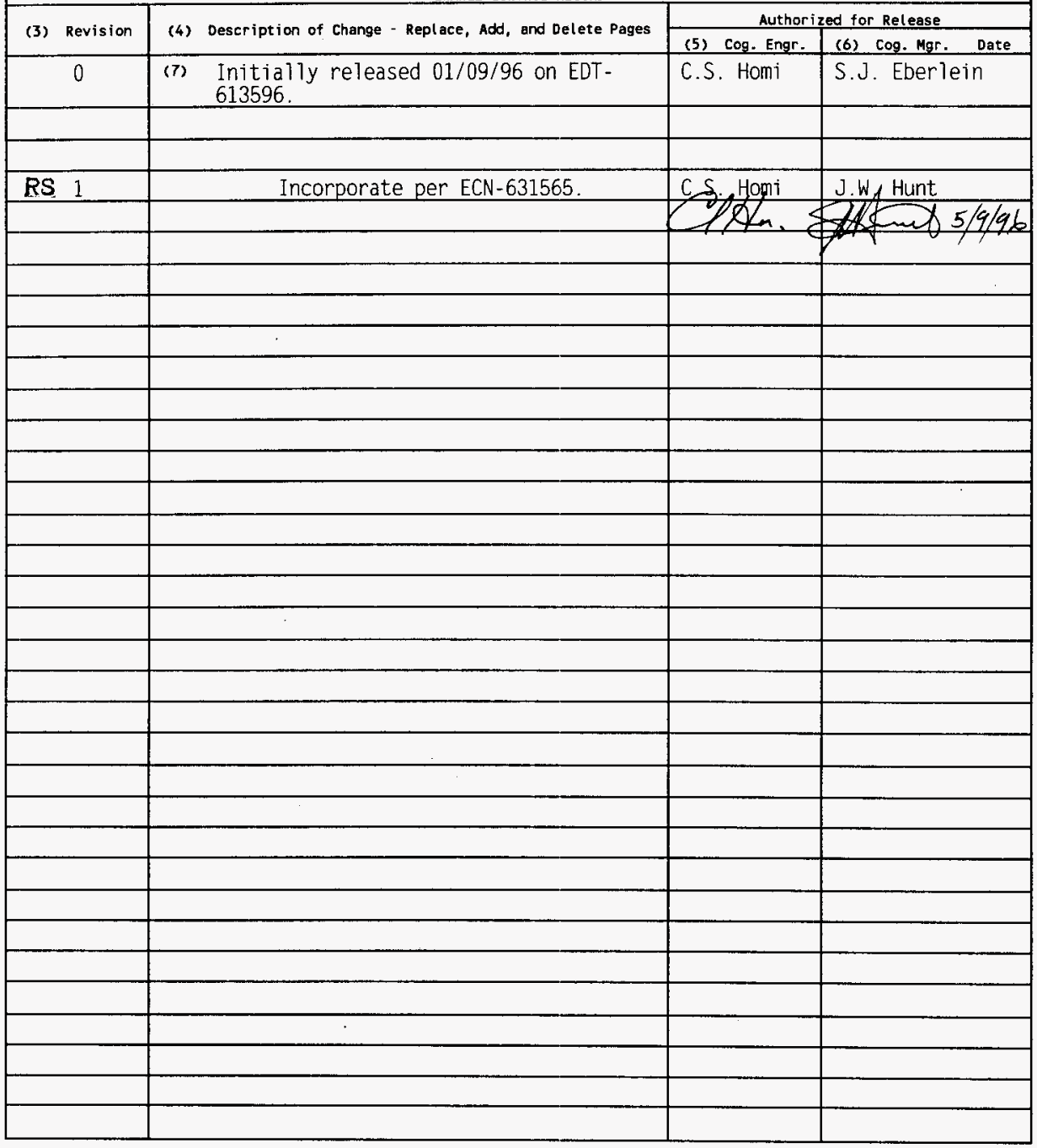

(1) Document Number

WHC-SD-WM-TP-424 
WHC-SD-WM-TP-424

Revision 1

UC-2070

\section{Tank 241-T-103 \\ Tank Characterization Plan}

W. D. Winkelman

Westinghouse Hanford Company

Date Published

May 1996

Prepared for the U.S. Department of Energy

Office of Environmental Restoration and

Waste Management

$\begin{array}{ll}\text { (20) Westinghouse } & \text { P.o. Box } 1970 \\ \text { Hanford Company } & \text { Richlad, Wastingtor }\end{array}$

Management and Operations Contractor for the

U.S. Department of Energy under Contract DE-AC06-87RL10930

Approved for Public Release 


\section{HHC-SD-WM-TP-424, REV 1}

TABLE OF CONTENTS

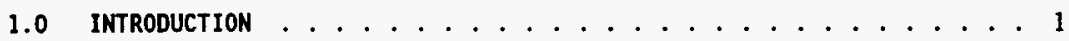

2.0 PROGRAM ELEMENTS REQUIRING INFORMATION FOR TANK 241-S-105 .... 2

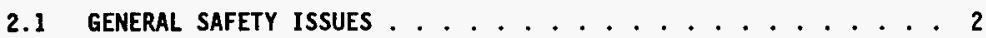

2.2 SPECIFIC SAFETY ISSUES .............. 2

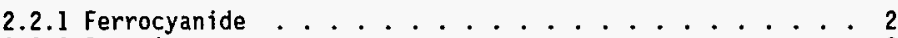

2.2 .2 Organic ................. 2

2.2 .3 High Heat .................2

2.2 .4 Flammable Gas . . . . . . . . . . . . . 2

2.2 .5 Vapor . . . . . . . . . . . . . . 2

2.2 .6 Criticality . . . . . . . . . 3

2.3 CONTINUING OPERATIONS ................. 3

2.3.1 Compatibility/Stabilization ............ 3

2.3.2 Evaporator . . . . . . . . . . . . . 3

2.4 DOUbLE-SHELL TANK WASTE ANALYSIS PLAN ......... 3

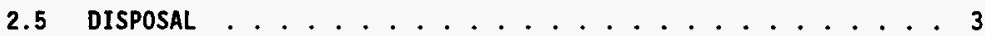

2.5.1 Retrieval .................. 3

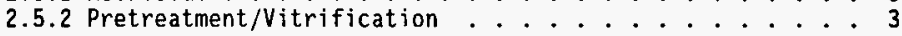

2.6 HISTORICAL MODEL EVALUATION . . . . . . . . . . . 4

3.0 HOW INFORMATION WILL BE OBTAINED .............. 4

4.0 PRIORITY OF INFORMATION REQUIREMENTS ............... . . 4

5.0 WHEN INFORMATION WILL BE AVAILABLE ............ 5

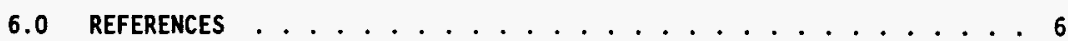

\section{IIST OF TABLES}

4-1 Integrated DQO Requirements and Priorities....... 4 


\section{WHC-SD-MM-TP-424, REV 1}

\subsection{INTRODUCTION}

This Tank Characterization Plan (TCP) identifies the information needed to address relevant issues concerning short-term and long-term safe storage and long-term management of single shell tank 241-T-103 (T-103). It should be understood that the various needs and issues surrounding tank $T-103$ are evolving as new information about the tank is uncovered. As a result of this progression, this TCP addresses only the issues that, to this date, have been identified. It is expected that deviations from this plan may occur as additional issues or needs arise which impact the management of tank T-103. As necessary, this TCP will be revised to reflect those changes or deviations. This plan reflects the best information available as of May 1996.

Tank T-103 was constructed between 1943 and 1944 and was put into service in November 1945. Tank 241-T-103 began receiving metal waste from the cascade overflow line connected to Tank 241T-102 in November 1945 and was full in February 1946. The tank was declared an assumed leaker and was removed from service in 1974 . The tank was interim stabilized in November 1983 with intrusion prevention completed in August 1981. A level adjustment was made in November 1983. The tank is classified as an assumed leaker stabilized tank. For a more complete history of the waste in this tank refer to the supporting document

(Brevick et al. 1995).

Tank T-103 currently contains a total waste volume of $102 \mathrm{~kL}$ (27 kgal), which is equivalent to $14 \mathrm{~cm}$ (5 in) of waste as measured from the baseline of the tank (Hanlon 1996).

This tank is not on any watch List.

Near-term sampling and analysis activities are focused on either verifying or changing the watch List tank status, and identifying any new safety issues. Should any safety issues be identified, additional analysis will occur consistent with the identified issue.

In addition to the resolution of the safety issues, it is intended that all tank waste will be subject to pretreatment and retrieval to prepare for final storage or disposal. Presently, these long-range plans have yet to be fully identified and are, therefore, not included in this document. 
WHC-SD-WM-TP-424, REV 1

\subsection{PROGRAM ELEMENTS REQUTRING INFORMATION FOR TANK 241-T-103}

This section identifies the various program elements, and identifies which of these programs require characterization data from tank $\mathrm{T}-103$.

\subsection{GENERAL BAFETY ISSUES}

The Tank Safety Screening Data Quality objective (Dukelow et al. 1995) describes the sampling and analytical requirements that are used to screen waste tanks for unidentified safety issues. Analytical requirements for the safety screening of a tank are energetics, total alpha activity, moisture content, density and flammable gas concentration.

\subsection{SPECIFIC BAFETY ISSUES}

\subsubsection{Ferrocyanide}

This tank is not on the Ferrocyanide watch List; therefore, no information needs are currently identified for this program element.

\subsubsection{Organic}

This tank is not on the organic watch List; therefore, no information needs are currently identified for this program element.

2.2.3 High Heat

This tank is not on the High Heat watch List; therefore, no information needs are currently identified for this program element.

\subsubsection{Flammable Gas}

This tank is not on the Flammable Gas Watch List; therefore, no information needs are currently identified for this program element.

\section{2 .5 Vapor}

A11 177 underground tanks must be vapor-sampled for organic solvent screening as per Recommendation 93-5 Implementation Plan (DOE-RL 1996). Some tanks may require additional vapor sampling due to other program needs. These tanks may be classified into four categories: (1) those tanks which are to be rotary mode core sampled (as a consequence of the rotary sampling system exhauster permit requirements); (2) tanks on the Organic or Ferrocyanide Watch Lists; (3) tanks in C farm; and (4) tank 241-BX-104, due to vapor exposure. Information needs must satisfy Data Quality Objectives for Tank Hazardous Vapor 
Safety Screening (0sborne and Buckley 1995), and for rotary mode only, Rotary Core Vapor Sampling Data Quality objective (Price 1994) and Data Quality objective for Regulatory Requirements for Hazardous and Radioactive Air Emissions Sampling and Analysis (Mulkey and Markillie 1995) as amended by Status of the Current Understanding of the Toxic Air Pollutants (TAPS) and Hanford Tank Farm Vapor Space Characterization; Recommended Path Forward and Justification for Continued RMCS Exhauster Operations (Laws 1996).

\subsection{6 criticality}

No information separate from that for the general safety issue of tank T-103 are currently identified for this program element. However, if the general safety screening of tank T-103 identifies a potential criticality concern, analyses for fissile materials and neutron sorbers and poisons will be performed as identified in the safety screening data quality objective.

\subsection{CONTINUING OPERATIONS}

\subsubsection{Compatibility/stabilization}

This section does not apply to tank T-103.

2.3.2 Evaporator

This section does not apply to tank $\mathrm{T}-103$.

\subsection{DOUBLE-SHELL TANR WASTE ANALYSIS PLAN}

This section does not apply because tank $T-103$ is a singleshell tank.

\subsection{DIBPOBAL}

\subsubsection{Retrieval}

current retrieval needs (Bloom and Nguyen 1995) do not call for test samples to be taken from tank $\mathrm{T}-103$.

\subsubsection{Pretreatment/vitrification}

Tank T-103 has been identified as a bounding tank for pretreatment/disposal process development strategy (Kupfer et al. 1995). The strategy only requires that sample material be made available via archive samples and does not require any specific analyses to be done on the samples. 
WHC-SD-WM-TP-424, REV 1

\subsection{HISTORICAL MODEL EVALUATION}

Bounding tanks and data requirements for historical model evaluations are found in Historical Model Evaluation Data Requirements (Simpson and McCain 1995). Tank T-103 is not identified as a primary bounding tank for historical model evaluations.

\subsection{HOW INFORMATION WILL BE OBTAINED}

The number of samples required to characterize a tank is a function of waste heterogeneity and the desired confidence to make a correct decision. As directed by the safety screening $\mathrm{DQO}$, if inadequate information exists to determine an appropriate number of samples, two vertical profiles will be obtained. These vertical profiles may be obtained using core, auger (for shallow tanks), or grab samples. Tank T-103 contains very little waste which appears from a video to be mostly liquid. Grab sampling was therefore chosen as the primary method to obtain the required samples. If analysis of these profiles reveals that additional profiles are necessary to meet data needs, more sample profiles will be requested.

\subsection{PRIORITY OF INFORMATION REQUIREMENTS}

Grab sampling is scheduled in May 1996. Auger Sampling is scheduled in August 1997. Vapor sampling is scheduled in December 1997 (Stanton 1996). Refer to Table 4-1 for the current $D Q O$ requirements and planned sampling and analytical requirements.

Table 4-1: Integrated DQO Requirements and Priorities

\begin{tabular}{|l|l|l|l|}
\hline $\begin{array}{c}\text { Sampling } \\
\text { Event }\end{array}$ & \multicolumn{1}{|c|}{ Applicable Issues } & Sampling Requirements* & Analytical Requirements \\
\hline Vapor & $\begin{array}{l}\text {-Organic Solvent Layer } \\
93-5 \text { Vapor Issue } \\
\text {-Hazardous Vapor DQ0 }\end{array}$ & $\begin{array}{l}\text { Steel Canisters, } \\
\text { Triple Sorbent Traps, } \\
\text { Sorbent Trap Systems }\end{array}$ & $\begin{array}{l}\text { Flammable Gas } \\
\text { Organic Vapors } \\
\text { Permanent Gases }\end{array}$ \\
\hline \hline $\begin{array}{l}\text { Grab and } \\
\text { Auger } \\
\text { Sampling }\end{array}$ & -Safety Screening DQO & $\begin{array}{l}\text { 2 grab samples each } \\
\text { from 2 risers. } \\
\text { 2 Auger Samples each } \\
\text { from 2 risers } \\
\text { Combustible gas } \\
\text { measurement }\end{array}$ & $\begin{array}{l}\text { Flammability, Energetics, } \\
\text { Moisture, Total alpha } \\
\text { activity, Specific } \\
\text { gravity or density }\end{array}$ \\
\hline
\end{tabular}


WHC-SD-WM-TP-424, REV 1

\subsection{WHEN INFORMATION WILL BE AVAILABLE}

According to Stanton (1996) data are expected to be available from the grab sampling event for tank T-103 in September. 1996. The auger sampling data are expected in December 1997. The vapor data are expected in January 1998. These times may be altered if the sampling schedule changes. 


\section{WHC-SD-WM-TP-424, REV 1}

\subsection{REFERENCES}

Bloom, G. R. and Q. H. Nguyen, 1995, Characterization Data Needs for Development, Design and Operation of Retrieval Equipment Developed Through the Data Quality Objective Process, WHC-SD-WM-DQ0-008, Rev. 0, West inghouse Hanford Company, Richland, Washington.

Brevick, C. H., L. A. Gaddis, and W. W. Pickett, 1995, Historical Tank Content Estimate for the NorthWest Quadrant of the Hanford 200 West Areas, WHC-SD-WM-ER-351, Rev. 0, Westinghouse Hanford Company, Richland, Washington.

DOE-RL, 1996, Recommendation 93-5 Implementation Plan, DOE/RL-94-0001, Rev. 1, U.S. Department of Energy, Richland, Washington.

Dukelow, G. T., J. W. Hunt, H. Babad, and J. E. Meacham, 1995, Tank Safety Screening Data Quality Objective, WHC-SD-WM-SP-004, Rev. 2, Westinghouse Hanford Company, Richland, Washington.

Hanlon, B.M., 1996, Waste Tank Summary for Month Ending January 31, 1996 , WHC-EP-0182-94, Westinghouse Hanford Company, Richland, Washington.

Kupfer, M. J., W. W. Schultz, and J. T. Slankas, 1995, Strategy for Sampling Hanford Site Tank Wastes for Development of Disposal Technology, WHC-SD-WM-TA-154, Rev. 1, Westinghouse Hanford Company, Richland, Washington.

Laws, G. L., 1996, Status of the Current Understanding of the Toxic Air Pollutants (TAPS) and Hanford Tank Farm Vapor Space Characterization; Recommended Path Forward and Justification for Continued RMCS Exhauster Operations, (telephone conference memorandum 01830-96-022, to Distribution, March 8), Westinghouse Hanford Company, Richland, Washington.

Mulkey, C.H., and K. D. Markillie, 1995, Data Quality Objective for Regulatory Requirements for Hazardous and Radioactive Air Emissions Sampling and Analysis, WHC-SD-WM-DQ0-021, Rev. 0, Westinghouse Hanford Company, Richland, Washington.

Osborne, J. W., and L. L. Buck7ey, 1995, Data Quality Objectives for Tank Hazardous Vapor Safety Screening, WHC-SD-WM-DQ0-002, Rev. 2, Westinghouse Hanford Company, Richland, Washington.

Price, D. N., 1994, Rotary Core Vapor Sampling Data Quality Objective, WHC-SD-WM-SP-003, Rev. 0, Westinghouse Hanford Company, Richland, Washington.

Simpson, B. C., and D. J. McCain, 1995, Historical Model Evaluation Data Requirements, WHC-SD-WM-DQ0-018, Rev. OA, Westinghouse Hanford Company, Richland, Washington. 


\section{WHC-SD-WM-TP-424, REV 1}

Stanton, G. A., Baseline Sampling Schedule, Change 96-02 (Internal memo 75610-96-06, to Distribution, Apri1 17), Westinghouse Hanford Company, Richland, Washington. 


\begin{tabular}{|c|c|c|c|c|c|}
\hline \multicolumn{6}{|c|}{ DISTRIBUTION SHEET } \\
\hline \multirow{2}{*}{$\begin{array}{l}\text { To } \\
\text { Distribution }\end{array}$} & \multirow{2}{*}{\multicolumn{3}{|c|}{$\begin{array}{l}\text { From } \\
\text { Evaluation and Planning }\end{array}$}} & \multicolumn{2}{|l|}{ Page 1 of 1} \\
\hline & & & & \multicolumn{2}{|c|}{ Date $\quad 05 / 09 / 96$} \\
\hline \multicolumn{4}{|l|}{ Project Title/Work Order } & \multicolumn{2}{|c|}{ EDT No. $N / A$} \\
\hline \multicolumn{4}{|c|}{$\begin{array}{l}\text { WHC-SD-WM-TP-424, Rev. 1, "Tank 241-T-103 Tank Characterization } \\
\text { Plan" }\end{array}$} & \multicolumn{2}{|c|}{ ECN No. ECN-631565 } \\
\hline Name & MSIN & $\begin{array}{l}\text { Text } \\
\text { With } \\
\text { All } \\
\text { Attach. }\end{array}$ & Text Only & $\begin{array}{l}\text { Attach./ } \\
\text { Appendix } \\
\text { Only }\end{array}$ & $\begin{array}{c}\text { EDT/ECN } \\
\text { Only }\end{array}$ \\
\hline
\end{tabular}

\section{ONSITE}

U. S. Department of Eneray -

Richiand Field office

W. Liou

N. W. Willis

S7 $-54 \quad \underline{x}$

S7-54 $x$

Westinghouse Hanford Company

G. D. Forehand

C. S. Homi

W. D. Winkelman

S7-21 $\quad X$

R2-12 $\quad X$

$R 2-12 \quad x$

Central Files

T.C.R.C.

A3-88

$\mathrm{R} 2-12$

$\hat{x}$

\section{OFFSITE}

U. S. Department of Enerqy - Headquarters

office of Environmenta 7 Restoration and Waste Management EM-563

12800 Middlebrook Road

Germantown, MD 20874

J. A. Poppiti

$x$ 